\title{
Reflecting and Verbalizing Teaching - Supported by Didactic and Digital Tools
}

\author{
Marita Cronqvist \\ Faculty of Librarianship, Information, Education and IT, University \\ of Borås, Sweden \\ marita.cronqvist@hb.se
}

\begin{abstract}
In teacher education, it is problematic to intertwine theory and practice. It is also problematic that student teachers lack self-awareness about what values they express in their meetings with pupils. They need to reflect and verbalize their teaching experiences. In this article, results from a study in teacher education are presented from a development work where a combination of a didactic tool that visualizes ethics in teaching and a digital tool, video paper is tried. The purpose is to investigate how this combination can stimulate student teachers' reflections on their teaching during their internship and through follow-up in the campus course. Findings indicate that the tools in themselves are not enough to bridge theory and practice. However, the tools can be helpful to teacher educators. Reflections presented in video papers are quite different in content, range and depth which are visualized through the questions of the didactic tool and by different typologies for reflection. The reflections show that there are many ways to verbalize ethics which raises questions about what it really means to visualize ethics.
\end{abstract}

\section{Keywords}

video paper - didactic - reflections - theory and practice - ethics

\section{$1 \quad$ Introduction}

In teacher education, reflection is central to learning and developing a professional role. According to Dewey (1933), reflections make teaching more 
responsible and thoughtful. Reflections can be different in many ways, quite superficial, more profound and about different contents, for example subjects, performance or ethics. Luttenberg and Berger (2008) have noticed that different levels of reflections, for example when the reflections change from being subjective to more abstract and theoretical, are related to changes also in content. Reflections are sometimes described as critical and should then include questions like what and why in order to get a deeper understanding of teaching (Gun, 2011). However, critical reflections can be understood differently. Luttenberg and Berger (2008) exemplify how critical reflection can involve a willingness to change and develop. It is common to use the word reflection without explaining the meanings, both in general and in research. Different ways to interpret and understand reflection used in this study is further presented as theoretical framework. The aim of the didactic tool that is used is to visualize ethics by asking questions about ethical aspects of teaching. The tool is based on common didactic questions but expands the understanding of the questions (Cronqvist, 2017). The question "what" can for example include aspects of values and attitudes that can be presented together with a specific content. A presentation about healthy living, can be combined with values and attitudes that are related to health or with values that the class needs at the moment. There is a difference between teaching ethics and teaching ethically (Osguthorpe, 2008). The former means that the teacher is telling the pupils how to behave or what ethics is. The other means that the teacher is a role model and behave respectfully or reliable. In this context, it is the student teachers' development to teach ethically, being a role model which is of interest. To become a role model, self-awareness through reflection is needed (Schussler, Stooksberry and Bercaw, 2010). It is not obvious what it means to teach ethically but a leadership that develops through questions about how to approach pupils in school needs attention.

In the present study, the aim is to investigate how a combination of didactics where questions about ethical aspects in teaching are prominent and video paper, a multimedia document with videos and reflective texts, can stimulate student teachers' reflections on their teaching during their internship and through follow-up in the campus course. The research question is what characterizes student teachers' reflections on teaching connected to their possibility to observe themselves and to the questions raised by the didactic tool. The question is important in order to understand how reflections can be 
developed through teacher education. The material consists of video papers from a course in Swedish didactics in second semester of teacher education.

\section{The Didactic Tool}

The reason to use a didactic tool to visualize ethics is that further research about ethics in teaching and how to learn about teaching ethically is needed. Earlier research indicate that it is problematic to identify ethics in teaching (Todd, 2008), to verbalize it (Colnerud \& Granström, 2002; Sockett \& LePage, 2002; Thornberg, 2008) and to base ethics on knowledge (Campbell, 2003). In teacher education there is a lack of attention to ethical aspects of teaching (Sanger \& Osguthorpe, 2011).

The didactic tool consists of three phases of teaching, planning, implementation and evaluation. These phases represent partly different views of teaching that need to complement each other. In the planning phase, applied ethics (Campbell, 2003) is used. This means that certain values can be chosen and adapted to the content presented to pupils. In implementation phase you meet children with different needs and in this communication, ethics is implied (Todd, 2008). You can never plan every detail of implementation since the pupils act and react on your planning. In that way, ethics is always also implied as inherent in teaching. So in each situation, student teachers need to develop their judgement. These both perspectives and also the evaluation of teaching are part of didactics used in the current course in Swedish. As ethics to a great extent is inherent in teaching, the knowledge about how to teach ethically is considered to be a tacit knowledge (Colnerud \& Granström, 2002; Orlenius \& Bigsten, 2013; Sockett \& LePage, 2002; Thornberg, 2008) and it needs to be verbalized to facilitate learning in teacher education.

Difficulties to verbalize ethics is a complex problem connected to the problem that ethics often is handled as personal issues and not based on theories from research or proven experience. There are several possibilities to verbalize ethics according to research. Colnerud and Granström (2002) identifies three different types of languages, one everyday language, one theoretical language and the third is a mix between the two mentioned. They argue that the theoretical language is largely missing and is crucial to develop the profession. Some researchers (for example Klaassen, 2002) do not describe a certain kind of language but express a need for a language different than the 'businesscontractual, formal-organizational approach that is currently found in schools.' ( $\mathrm{p}$ 158). Maybe is he searching for the alternative that Van Manen and Li (2002) present, namely narratives that focus on experiences, feelings, beliefs and so 
on. Other ways of verbalizing ethics in teaching can be through dilemmas (Husu \& Tirri, 2003) and codes of ethics (Maxwell \& Schwimmer, 2016). Student teachers' reflections can give a picture of their way to express ethics in teaching.

4

\section{Video paper}

Video paper is a multimedia document, integrating clips of video recordings and reflective texts based on the clips (Lazarus \& Olivero, 2009). The filming gives student teachers a possibility to observe themselves afterwards and to reflect on many different aspects of their teaching (Mastas and Dooly, 2011). The possibility to view and review can contribute to reflection on various areas, perspectives or levels (Richardson and Kile, 1999). Since some time is passing between teaching, filming and reflecting, a distance that can stimulate reflecting (Bengtsson, 1995) is enabled. Video paper can also be an inspiration to select clips that highlight certain key aspects of teaching instead of describing the teaching chronologically (Sherin, 2004). The combination of filming and reflecting can support bridging practice and theory (Dieker et al., 2009; Seidel, Blomberg \& Renkl, 2013; Masats, \& Dooley, 2011). The recordings give student teachers time to reflect on what happened during a longer period and to merge situations from practice with course content. However, it is difficult for student teachers to handle the process of self-reflection (Sitzmann et al., 2010; Kleinknech \& Gröschner, 2016) and to merge theory and practice. Seidel et al. (2013) argue that video paper in itself is not effective. Student teachers need support from educators (Eriksson, 2009) and the effectiveness is depending on how it is integrated with instructions (Blomberg et al., 2013).

Theoretical Framework

Reflection is a concept frequently used in teacher education since the 1980 s (Ubani, 2016). Not even in research, it is always explained, which can be problematic because there are many ways to interpret and understand the concept. Bengtsson (2007) explains the notion as a complement between thinking and self-understanding. In reflection, awareness is not directed towards the world but towards the self and a distance is created. Reflection is considered as a useful tool in teacher education, not least the benefit of self-awareness. Many researchers are mentioning critical reflection, sometimes without explanations. 
Both Dewey (1933) and Boud (1985) describe reflection as a way to be critical and to carefully consider beliefs or experiences and a way to gain a new understanding. In this study, it is relevant to understand reflection as a tool to create distance to yourself and consider experienced situations. Reflection is also relevant to understand your own values or beliefs and to have an opportunity to be critical, reconsider and think new. Schussler, Stooksberry and Bercaw (2010) describe how student teachers' reflections showed more awareness of their teaching through questioning the how and why of their thinking and actions, through focus on both pupils and themselves and through the ability to adopt several perspectives. Research indicates suggestions about different levels of reflection. Sockett and LePage (2002) mention three levels of reflection: a) at the narrative level, reflections are descriptions of what happened and explanations of circumstances. The content is personal and concrete. b) At the self-justifying level, focus is on your own qualities. You are not being able to see your shortcomings. At this level, there is an endeavor to make "right" in relation to an imaginary authority. c) At the self-critical level, the focus is on improvement and change. The teacher is willing to try new things and moral issues of teaching are central. Another typology (Surbeck, Han \& Moyer, 1991) describes the first level (reaction) as personally feelings, concerns and facts about your own experiences. The second level (elaboration) implies reactions on the concrete situation and then further elaboration by comparing two experiences and to suggest a general principle or theory. The third level, contemplation, implies reaction and elaboration and a further concern for personal, professional and social/ethical matters. Van Manen (1997) too describes a third level as dealing with moral and ethics, which he calls critical reflection.

The reflections in this study are examined using the different typologies presented as inspiration to find patterns among reflections. One part of the analysis is what student teachers' decide to reflect on. Another part is to examine different levels from data. According to Luttenberg and Berger (2008), it can be problematic to separate content and levels. In this study, separate analyzes were performed since the content was analyzed based on the didactic tool.

\section{6} Method

\subsection{Participants}

The study was conducted in conjunction with one of the courses in teacher education. Video paper connected to internship was an examination task. 
All student teachers that participated in the examination task also agreed to participate in the study by written consents. The participants are 13 student teachers, studying to become subject teachers, teaching pupils aged $13-16$ years. The student teachers are studying their second semester in an education that includes 9 semesters.

\subsection{Data Collection}

The course in which the study is conducted is a subject course in the subject Swedish. This course comprises two weeks of internship when student teachers are supposed to film themselves during some lessons when they are teaching. As a preparation for internship, a didactic tool using common didactic questions (what, to whom, why and how), focusing on ethics in teaching, was presented. The didactic tool holds questions about values, norms, attitudes and so on to pay attention to ethics in teaching. Back to campus the student teachers select some video clips and write reflections to them. They have a seminar when they are presenting their clips and reflections to the group, followed by a discussion. Based on this seminar they can revise their reflections before submission. The submitted video papers constitute the data of this study. The presentations last for about five minutes. Most of the video papers comprise three to four clips and include 1-2 pages.

\subsection{Analysis}

Content analysis was used to examine data. The analysis started by reading the video papers several times to get an idea of the whole and to get familiar with the texts. In the next step, different parts of reflection are identified based on content and level, inspired by the theoretical framework. This reading process is an inductive and very systematic process (Thomas, 2006). The researchers' preunderstanding and expectations must be hold back, bridled, questioned and reflected on (Dahlberg, Dahlberg \& Nyström, 2008). Since the categories appear through the analysis, the coding is called emergent coding unlike priori coding when the categories are decided in advance (Stemler, 2001). After the coding process, different patterns in the data are searched for. Categories are put together in groups in a process when various possibilities are tried and discussed between colleagues. This is a process of abstraction (Elo \& Kyngäs, 2008).

The didactic tool that has been used is based on an empirical study about professional ethics (Cronqvist, 2015, 2017). In that study the essential meanings of professional ethics was constituted by seven meaning elements (1-7). In the didactic tool these meaning elements are used but in different parts, planning, 
implementation and evaluation. The planning consists of two parts, what and how. The questions of the first part, what, are:

What content is presented? What perspectives of the content are presented?

Which levels can be identified?

Is some part of the content current?

What attitude to the content is desirable?

What values can be connected to the content?

The last questions are about meanings of professional ethics. What does it mean to...

...interweave learning with relationships and feelings? (1)

...use your own experiences? (2)

...create participation to each child? (3)

...create an atmosphere of joy, safety and respect? (4)

The questions of the second part, how, focus on methods:

How is the work organized, individually / pair / group / all varied?

How does work vary by writing / reading / talking / listening / showing / doing?

Do you need to use...

...subject methods, multimodality, support structures to meet different needs, digital tools, other tools?

How is location and structure of the room organized?

How is the environment?

How does the activity begin and end?

How is activity motivated?

How do you work with body language, voice and word choice?

How is a dialogue conducted? What kind of questions do you ask? How do you respond to answers?

How do you confirm children?

How is the work assessed and evaluated?

In the didactic tool, it is important to start with the question what. Not until you have decided about the content and intentions about ethics related to the content, you can think about how you are going to proceed. 
In the implementation part, the same questions are asked but further two of the meanings of professional ethics are added:

What choices are made visible in the situation? What decisions are made? (5)

Are there any obstacles? (6)

In the evaluation part of the didactic tool, another meaning is added:

How can experiences in practice (positive and negative) be related to different theories? (7)

The themes of the content are analyzed in comparison to the didactic tool to find out if the tool has stimulated the student teachers' reflections. The content of the reflections are therefore connected to the tool and the levels are analyzed with inspiration from the typologies about reflections.

Since teaching always implies ethics, whether there is awareness of it or not, there are no separate ethical areas when the content of the reflections is presented. All content in student teachers' reflections is related to ethics according to the didactic tool that merges content, ethics and methods. All quotations from the video papers have been translated from Swedish which makes it difficult to always find exact words.

There are different themes connected to the didactic tool as content in student teachers' reflections. Several of the questions in the didactic tool are reflected as a part of pupils' possibilities to participate. This is the most prominent theme. Participation can be divided into dialogue, meeting different levels, motivation, performance and use of digital tools. Other themes are relationships, atmosphere of joy, respect and safety and view on planning and presence. Overall, the papers are quite different. Some of them are dominated by chronologically descriptions of what happened in the classroom. This can be understood as a level of reflection (Sockett \& LePage, 2002) but is different from other papers where student teachers explain how they understand the situations. Some papers contain reflections on several different contents while others reflect on one or few issues.

\subsection{Participation}

The didactic tool defines inclusion as pupils' possibilities to participate. Student teachers uses the word participate frequently and inclusion a few times. 


\subsubsection{Dialogue}

Student teachers reflect on the interaction with the pupils. They strive for a communication that ensures the pupils to participate, for example ask questions, answer questions and express their views. With a good communication, the student teacher can find out whether or not the pupils are involved.

Anna: It is also important that I take into account how I follow up the pupils' answers, for example, to avoid short responses to the pupil. In short responses, the pupil does not get enough encouragement.

Anton: I introduce the subject and make attempts to include all pupils and create participation by asking questions.

Ellen: One suggestion of how this could be improved is that I can try to get pupils to explain what we went through in the previous lesson. In this way, I include pupils more in my teaching.

Elsa and Lena reflect on that it sometimes is useful to ask leading questions, if they want the pupils to understand a particular perspective or if they want to verify their knowledge about something. Another reflection is that student teachers realize that they have to wait for answers. Since they think silence is troublesome they move on. Katarina reflects:

I have to dare to be patient and not too quick with the conclusions. It is not me but the pupils that need to draw them. I have to dare let it take time and not control them. As a teacher, you can walk beside them on the path and not in front of them.

Mostly, the student teachers take responsibility to involve the pupils but Annika instead expresses her responsibility to invite them:

By asking questions to the pupils during the lesson, I show that I expect response and participation from them.

7.1.2 Meeting Different Levels and Motivation

Other reflections that can be connected to participation are to meet different levels and interests of the pupils in order to involve them and support their participation and learning. Alicia reflects on a girl that completed the task quickly:

This poses questions such as: Does this pupil need a somewhat more challenging task than the others? 
Alicia thinks it is important to offer more ways to talk about the same subject in order to increase the pupils' possibilities to understand. Ellen connects pupils' interest and motivation to how she relates to them:

I ask, "Do you understand what I mean?" But get no answers and then continue talking. Here it would be good to take a second and try to figure out if the class actually agrees with my explanations or not.

To Birgitta and Ellen, various methods can meet different levels and in that way support pupils' learning.

Birgitta: The EPA ${ }^{1}$ method is used to make all students' voices heard. This method is a promotion as it creates an involvement for each student and its learning.

Ellen thinks she has to explain the method better to the pupils. Some of them did not use the method but she does not know why. Maybe the method does not work for them or....

"... I would not have been sufficiently clear about the benefits of the method. Regardless, a clearer explanation about this example would have been good for all pupils to accommodate everyone's levels".

\subsubsection{Performance}

Student teachers' reflections on their performance give a picture that they feel unsure, nervous and that exercises by performing over and over again give them security and self-confidence. The most common reflections are about body language and how they use their voice. They comment about looking into the whiteboard, how they manage to have eye-contact with the pupils, how they stand and make gestures. The filmed sequences give them opportunity to listen to how they use their voices. This, and also body language, is very difficult to capture without filming. They comment about their tone mode, if they speak loudly, what tempo they have, how they use pauses and how engaged they sound. In this part, focus is mostly on the student teachers themselves, and they are predominantly self-critical. Alicia writes:

1 This method means that you work alone (E: ensam/alone) at first and then in pair (P: par/ pair) and finally all together (A: alla/all). 
I, as an educator, will engage students in their school work, this could be better if I try to talk with a happier mood and also with louder voice

Even if she reflects on her own performance, it is connected to how she can interact with and motivate pupils to work.

7.1.4 Digital Tools

The choice of using or not using digital tools seems to be a choice of pupils' possibilities to be involved and really participate. Most student teachers are using digital tools but reflect on difficulties and possibilities in various situations.

Digital tools can support the teacher to be more engaged in interaction with pupils but using the whiteboard can also enable it. Alicia explains that she chose not to use a power point presentation to avoid monologue and to give the pupils better opportunities to participate in the discussion. But she realizes the possibilities of digital tools. She writes:

If there had been a smartboard, I could have done a power point presentation and then had the opportunity to write notes or questions, views and ideas from the pupils.

One of the difficulties of using the whiteboard is that the student teachers turn their back on the pupils. They find it problematic to write and at the same time interact with the pupils. Using digital tools help them to focus on interaction. There are many reflections about how digital tools give opportunities to stimulate learning. Annika reflects on possibilities to learning when the pupils had access to the app Showbie on their Ipads:

This allowed the pupils to look at the document whenever they wished.

Petra uses Kahoot and believes that the pupils in that way can confirm their understanding of the power point. She writes:

Each pupil is included through individual thinking and gets a repetition that is amusing.

Alicia reflects that the pupils can prefer to use or not use digital tools and therefore let them choose when they worked with key words and a summary. Lotta, who frequently uses digital tools, reflects on the difficulty of starting a lesson when the pupils show up without their Ipads: 
It may take a long time to get started and the rest of the class is waiting. Situations such as these should be avoided or, as said, prevented.

Lotta reflects on different ways to avoid this problem, for example to meet the pupils at the door, have pictures of Ipads in the classroom, to write reminders on the whiteboard. Obviously, various aspects of participation are a main part of student teachers' reflections.

\subsection{Relationships}

Relationship between student teacher and pupils is an aspect that concerns several meanings of professional ethics. Knowing or not knowing the class is crucial to adaptation to different levels. Lena reflects:

Given that I did not know the class, it was difficult for me to adapt the lesson, more than to those students with special needs that I had been informed about in advance.

She also writes:

Something less good was my very impersonal way to teach. It was difficult to make connections to their own interests in teaching as well as making comparisons they could relate to. Unfortunately, I had not learned their name, so when someone raised their hand it was difficult to address them.

\subsection{Atmosphere of Joy, Respect and Safety}

Sometimes participation and learning is connected to different values, for example safety. Annika reflects:

To start every lesson with feedback from the last lesson can give both me and pupils security.

Stefan is also reflecting about how to create security in classroom. Asking questions about the pupils' knowledge is one way to involve them, create security and a pleasant working atmosphere. However, he also sees risks:

This would have created a better relationship and security to the pupils, but also created a risk that the lesson is losing track.

The interpretation of Stefan's reflections is that he sees a risk to invite the pupils. He thinks it is necessary to create participation, safety and a good 
atmosphere but at the same time has some fear that he loses control. When the pupils are invited to be active, the teacher's role gets more difficult because something unexpected can come up. Mikael expresses the same:

I notice during my internship that the pupils can ask about anything and it is therefore important to be prepared, knowing exactly what you are doing.

The student teachers are reflecting on how they need to really be present and use their judgment to make choices in the current situation.

Another value mentioned is respect. It is mainly Katarina who has a lesson about respect as subject that reflect on this value. She reflects on her attitude generally:

All answers were $\mathrm{OK}$ and it was important to me that all questions and claims are treated with openness and respect.

Katarina reflects that it is important to catch sight of several understandings of the value and not assuming that everybody thinks the same. Different meanings appeared during the lesson. The pupils' understanding of the value in one aspect made Katarina surprised. They thought they should obey adults even if they asked them to do something they felt was wrong.

Lena also reflects on respect:

As I want to keep the mood in the classroom as respectful as possible, I as a teacher must respect the wishes of my pupils. To get the respect you want from your pupils, you must show the same respect for them.

\subsection{Planning and Presence}

As reflections on the use of digital tools are characterized by a tension between different views, so are reflections on lesson planning. Student teachers agree that a rather precise lesson planning can be helpful. They mention different aspects where they feel that they could have been more precise:

Annika: If had had the opportunity to do this lesson again, I would have prepared examples for each option that was presented in advance.

Anton: Next time I introduce the task in the class, I will give some suggestions on areas that they can write about.

Elsa: Something I could have done differently would have been to have previously made groups. 
William: The lesson should have followed clear and short instructions rather than the momentum with an elaborate presentation.

The reasons why the students want to make more precise plans are both about avoiding trouble for themselves, but mainly about facilitating and clarifying for the pupils. They believed that things could be organized at the lesson or that they could think of options spontaneously but they did not have the routine required for that. It is both in subject and generally knowing how to express yourself that student teachers need to prepare more.

Katarina has a different view on planning. She realizes that interaction with pupils is depending on her ability to "respond and act together with the students involved on their own initiative". She is satisfied that she did not plan her lesson in detail but rather allowed pupils to participate and shape their learning based on what they give her. She reflects:

This is something I have embraced based on the ethical aspect of learning. There are people with feelings we work with and they may not always be shaped the way we want, right then.

Katarina's reflections indicate the tension between planning and being able to adapt the teaching to the pupils and the situation. This is an ability that perhaps cannot be expected from student teachers so early in the education.

\subsection{Level of Reflections}

Most reflections on participation are on social/ethical level (Surbeck, Han \& Moyer, 1991) since the responsibility to include everyone is in focus. The different themes are about how to reach the pupils, getting them to understand and learn. Student teachers' reflections on performance are to some extent an exception since they have attention to themselves. Therefore, they partly reflect on other levels than the social/ethical (Surbeck, Han \& Moyer, 1991). Student teachers are self-critical and see different possibilities to improve their teaching (Sockett \& LePage, 2002, van Manen, 1997). The improvements are about explaining better, to listen carefully and to control the pupils' learning. The second level of Surbeck, Han \& Moyer (1991), to compare different experiences and to suggest a general principle or theory, is not visible in data but can be noticed in one case. Ellen explains that she allows the page with instructions to be open so that all pupils easily can look back on it:

Some students may be shy and do not want to ask for help. Although I walk around the classroom after the review and make sure everyone has 
understood and agrees with what we are going to do, I may miss discovering these students. That is why I always make sure that the instructions are close to hand for all students.

Ellen has experienced that pupils ask her when she walk around the classroom but she has also experienced that she has missed some pupils and therefore she makes sure that she offers different possibilities through digital tools to the pupils to participate and understand the instructions.

The student teachers' reflections on performance are mostly very personal and concrete about what happened in interaction with the pupils. None of the participants reflect on the self-justifying level (Sockett \& LePage, 2002). All video papers are balancing between what went well and a critical voice. The reflections are to a great deal not only critical but do also include suggestions for improvements. Mikael writes:

I notice that when I read aloud, I stumble a little bit and it does not flow like I want it to do. In order to do it better for the next time, I can prepare myself by reading through the back of the book a few times before the lesson to get more flow.

When student teachers reflect on their experiences of planning, they realize that their planning needs to be more specific in different aspects. The reason for being more specific in planning is primarily to support pupils to participate and learn. Also in this theme there is an example of formulating a principle (Surbeck, Han \& Moyer, 1991). Katarina thinks it is important not to plan in detail because she wants to interact with the pupils, based on what they give her.

In summary, the reflections on participation are on an ethical level, selfcritical and suggesting improvement in several areas.

\subsection{Missing Content}

Parts of the didactic tool where reflections are few or completely missing are different perspectives, attitudes or values connected to the content student teachers teach about. They rarely mention relationships and feelings related to content but it can be due to their frequent reflecting on participation. It can also be due to a rather short period of internship (two weeks) which makes it difficult to create relationships to pupils. Reflections on how to use their own experiences are missing. One example of obstacles they mention is the filming, which affects both student teachers and pupils. For one of the participants, the supervisor can be interpreted as an obstacle since the student teacher wanted to act otherwise but felt impeded by the supervisor. The meaning of 
professional ethics that is about how experiences in practice can be related to theories is not found in data, except for one participant, referring to theories. The student teachers mention how they acted and that they could have acted otherwise but they do not express awareness of different choices during their teaching. Mostly, student teachers' content is based on formulations in the curriculum but there are a few examples of their own intentions:

Elsa: My main purpose of this lesson was to give the pupils a mindset, as well as practice discussing and conducting arguments. It is also an important part of the school's value-based work to teach pupils to respect each other despite possible prejudices.

Lena: Therefore, most of the time was spent talking about the text to give the pupils new thinking while giving them the opportunity to use their imagination.

Mikael: I could have tried to get the students to think about the way that the author has written some books, for example, if an author has had a tough upbringing, does it appear in the books?

Mikael is the only one who makes a meta-reflection: I think it is very useful to see yourself in this way through video papers because you really become self-critical and see what can be improved.

\subsection{Verbalization}

Student teachers' verbalization of their reflections can be described mostly as implicit and sometimes as explicit in relation to the didactic tool. The questions from the didactic tool can be identified in some expressions but in most cases, the questions are discernible and not explicit. Only two student teachers mention that they have used the didactic tool. An example of this implicit way of using the tool is that student teachers do not use the word atmosphere (atmosfär) from the tool but instead use the synonym sense (stämning). The student teachers' reflections consist of a narrative text with everyday words (van Manen \& Li, 2002). There are few examples of concepts like inclusion, values, norms, ethics and so on. This means that the theoretical language that Colnerud and Granström (2002) refer to is missing.

\section{Discussion}

The analysis of the student teachers' reflections indicates that the didactic tool to some extent has influenced the reflections since the pupils' possibilities to participate in learning dominate the video papers. According to the didactic 
tool the question what always comes first and then the question how. It is common that discussions about teaching start with how and that the performance is the main issue (Sterner, 2015). Campbell (2003) writes about the importance of having intentions as a teacher, knowing what you want to accomplish. Not until it is clear what you want, the question how becomes relevant. This tendency, to start with how, wanting to use specific methods or digital tools, is distinctive in the study. When the student teachers reflect on using digital tools it is connected to pupils' possibilities to participate but the main question is about digital tools. Participation and support of learning are effects from using digital tools. The reflections should, according to the didactic tool be about what it means to support pupils to participate. When you have decided what it means, then you can discuss and decide about how you achieve this. Digital tools can be part of that discussion.

In order to understand how reflections can be developed through teacher education, it is important to discuss what can be expected early in teacher education and how reflections are supposed to develop until the exam. According to theories about reflections mentioned (Sockett \& LePage, 2002; Surbeck, Han \& Moyer, 1991) one way to develop reflections could be from personal experiences, to comparison of experiences and to relate to theories or express own principles. In this study we have many examples of the first level but not on the second and the third. Then we need to discuss how these levels can be developed. Another way of progression can be from being personal to professional and at last reflect on social/ethical matters. It seems that reflections on ethical matters have been partially supported by the didactic tool. The reflections are also critical and different ways to act are suggested. This can be due to instructions that the student teachers should use headings like What functions? What can be improved? Since the student teachers reflect very differently, it can be valuable to decide how to proceed and what to be expected in various courses during the education. Something that all student teachers in this study can improve is the connection to theories and the use of concepts. The awareness of different options in experienced situations can also be developed and further discussed.

Schussler, Stooksberry and Bercaw (2010) describe the importance of being a role model. In order to teach ethically and not just ethics, student teachers need to develop their self-awareness of what values they are expressing. Only one of the participants explains that it is important to act or set a value in classroom if the pupils are going to learn what it means. Except awareness of body language and use of voice, video papers also contribute to that student teachers become aware of that they need to wait for the pupils to answer the questions and to draw conclusions. Courage is required to wait for their 
answers in spite of the frightening silence. A question raised in this study is how far the teacher's responsibility goes. Is it enough to invite pupils to participate and then expect them to take responsibility for participation or are more efforts needed. According to the meanings of professional ethics (Cronqvist, 2017 ) it is not enough to invite pupils to participate. If the pupils do not participate despite invitations, the responsibility needs to go further. As a teacher you cannot be satisfied until you have achieved your intentions which hopefully are to get every pupil included. Implementation of intentions is only possible to control if they are verbalized in the planning.

One problem discovered in this study is the need to exercise, that the student teachers express. Their weeks of internship are twenty during the whole education. This gives few possibilities to exercise. Somehow, different parts of teaching need to be developed during courses. Occasions to practice in the theoretical part must be offered. For example drama or simulation learning can be used and these suggestions need to be further examined in future research.

It is difficult to identify ethics in teaching and verbalize it (Colnerud \& Granström, 2002; Orlenius \& Bigsten, 2013; Sockett \& LePage, 2002; Thornberg, 2008). It is through talking about something as ethical that ethics is made visible. However, talking about digital tools as a way to support participation does not make it obvious that participation is an ethical aspect of teaching. One way to visualize ethics is to mention concepts as ethics, moral, values and so on in connection to different situations (Colnerud \& Granström, 2002). These expressions are unique in data even if a few values are mentioned. Ethical aspects of teaching are mostly implicit and verbalized with an everyday language. The narratives of student teachers are about their personal experiences, intentions, feelings and beliefs (van Manen \& Li, 2002). When concepts are missing, a way to understand and identify the narratives as ethical aspect of teaching can be to use a framework about ethics, for example the didactic tool presented in this article or some ethical code. Although the tool was used, verbalization of ethics was mostly implicit in data. Therefore, the tool in itself is not enough to visualize ethics or to bridge the gap between thinking and acting, but can be a support to frame ethics.

The result indicates that a balance between planning and being present is crucial in teaching. It is a common reflection that student teachers feel that they could have been more prepared. On the other hand, one of the students is content that she had left some areas without planning because she then was forced to be present and open to the children's communication. This is perhaps an area that can be developed through teacher education. It seems like a good start to be very specific and accurate in the planning but continuously try to be more open to what happens in the situation and to develop the judgment. 
Since reflections on a theoretical and more abstract level are mainly missing in data, the conclusion is that the tools only to some extent function to bridge the gap between practice and theory. However, in order to function better the tools seem to be depending on the instructions connected to them and on individual commitment from the educators (Blomberg et al., 2013; Eriksson, 2009 and Seidel et al., 2013). The tools can be supportive but a discussion about how to use them effectively in instructions and how to add individual support is needed. The didactic tool would probably function better if all educators, both at campus and at schools, refer to it.

Through this study, the issue about how to develop reflections in teacher education has been recognized and requires to be further researched. The theories of different levels of reflection need to be examined as possible tools of progression. The result indicates that the student teachers differs a lot in their reflections and therefore, the study raises questions about how to be supportive in an appropriate way for each individual.

\section{References}

Bengtsson, J. (1995). Självreflektionens gränser och möjligheter i läraryrket. Nordisk Pedagogik, 15(2), 72-87.

Bengtsson, J. (2007). Vad är reflektion? Om reflektion i läraryrke och lärarutbildning. I G. Strömqvist \& C. Brusling (Red.) Reflektion och praktik i läraryrket. (s. 81-96). 2., [rev. och uppdaterade] uppl. Lund: Studentlitteratur.

Blomberg G, Renkl A, Gamoran Sherin M, Borko H \& Seidel T. (2013). Five researchbased heuristics for using video in preservice teacher education. Journal for Educational Research Online 5(1): 90-114.

Boud, D. (Ed.), (1985). Reflection: turning experience into learning. London: Kogan Page. Campbell, E. (2003). The ethical teacher. Buckingham: Open University Press.

Colnerud, G. \& Granström, K. (2002). Respekt för läraryrket: om lärares yrkesspråk och yrkesetik. [Ny, rev. och uppdaterad utg.] Stockholm: HLS förl.

Cronqvist, M. (2015). Yrkesetik i lärarutbildning - en balanskonst. Diss. Göteborg: Göteborgs universitet, 2015. Göteborg. Available on the Internet: http://hdl.handle. net $/ 2077 / 38771$.

Cronqvist, M. (2017). Didethics - a didactic model including professional ethics. Nordisk Tidskrift för Allmän Didaktik, 3(1), 68-85.

Dahlberg, K., Dahlberg, H. \& Nyström, M. (2008). Reflective life world research. 2. ed. Lund: Studentlitteratur.

Dewey, J. (1933). How we think: a restatement of the relation of reflective thinking to the educative process. Boston: Heath. 
Dieker L.A., Rodriguez J.A., Lignugaris/Kraft B., Hynes M.C. \& Hughes M.C. (2014). The Potential of Simulated Environments in Teacher Education: Current and Future Possibilities, Teacher Education and Special Education, Vol. 37(1) 21-33.

Elo, S. \& Kyngäs, H. (2008). The qualitative content analysis process. Journal of Advanced Nursing, 62, 107-115.

Eriksson, A. (2009). Om teori och praktik i lärarutbildning: en etnografisk och diskursanalytisk studie. Diss. Göteborg : Göteborgs universitet, 2009. Göteborg.

Gun, B. (2011). Quality Self-Reflection through Reflection Training. ELT Journal, 65(2) 126-135.

Husu, J. \& Tirri, K. (2003). A case study approach to study one teacher's moral reflection. Teaching and Teacher Education, 19(3), 345-357.

Klaassen, C.A. (2002). Teacher pedagogical competence and sensibility. Teaching and Teacher Education, 18, 151-158.

Kleinknecht, M. \& Gröschner, A. (2016). Fostering preservice teachers' noticing with structured video feedback: Results of an online-and video-based intervention study. Teaching and Teacher Education, 59, 45-56.

Lazarus, E. \& Olivero, F. (2009). Videopapers as a tool for reflection on practice in initial teacher education, Technology, Pedagogy and Education, 18 (3), 255-267.

Luttenberg, J. \& Berger T. (2008). "Teacher reflection: the development of a typology". Teachers and Teaching: Theory and Practice 14, 5-6, 543-566.

Masats, D. \& Dooly, M. (2011). Rethinking the use of video in teacher education: A holistic approach. Teaching and Teacher Education, 27(7) 1151-1162.

Maxwell, B. \& Schwimmer, M. (2016). Seeking the elusive ethical base of teacher professionalism in Canadian codes of ethics, Teaching and Teacher Education, 59, 468-480.

Orlenius, K. \& Bigsten, A. (2013). Den värdefulla praktiken:yrkesetik ipedagogers vardag. 2. uppl. (orig.2006). Stockholm: Liber.

Osguthorpe, R. D. (2008). On the Reasons We Want Teachers of Good Disposition and Moral Character. Journal of Teacher Education, 59(4), 288-299.

Richardson, V. \& Kile, R. (1999). Learning from videocases. In M. A. Lunderberg, B. B. Levin \& H. L. Harrington (Eds.), Who learns what from cases and how?: The research base for teaching and learning with cases (pp. 121-136). Mahwah, NJ: Lawrence Erlbaum Associates.

Sanger, M. \& Osguthorpe, R. D. (2011). Teacher education, preservice teacher beliefs, and the moral work of teaching. Teaching and Teacher Education, 27(3), 569-578.

Schussler, D.L., Stooksberry, L. M. \& Bercaw, L. A. (2010). Understanding Teacher Candidate Dispositions: Reflecting to Build Self-Awareness. Journal of Teacher Education, $61(4), 350-363$.

Seidel, T., Blomberg, G. \& Renkl, A. (2013). Instructional strategies for using video in teacher education. Teaching and Teacher Education, 34, 56-65. 
Sherin, M. G. (2004). New perspectives on the role of video in teacher education. In J. Brophy (Ed.), Using video in teacher education (pp. 1-27). NY: Elsevier Science.

Sitzmann, T., Ely, K., Bell, B. S. \& Bauer, K. (2010). The effects of technical difficulties on learning and attrition during online training. Journal of Experimental Psychology: Applied, 16 (3), 281-292.

Sockett, H. \& LePage, P. (2002). The missing language of the classroom. Teaching and Teacher Education, 18, 159-171.

Stemler, S. (2001). An overview of content analysis. Practical Assessment, Research \& Evaluation, 7, 137-146.

Sterner, H. (2015). Problematisera "görandet": lärares lärande om kommunikation och resonemang i matematikundervisningen i en organiserad praktikgemenskap. Licentiatavhandling Växjö : Linnéuniversitetet, 2015. Växjö.

Surbeck, E., Park Han, E. \& Moyer, J. (1991). Assessing Reflective Responses in Journals. Educational Leadership. 48(6), 25-27.

Thomas, D. R. (2006). A general inductive approach for analyzing qualitative evaluation data. American Journal of Evaluation, 27, 237-246.

Thornberg, R. (2008). The lack of professional knowledge in values education. Teaching and Teacher Education, 24(7), 1791-1798.

Todd, S. (2008). Att lära av den andre: Lévinas, psykoanalys och etiska möjligheter $i$ undervisning och utbildning. 1. uppl. Lund: Studentlitteratur.

Ubani, M. (2016). RE student teachers' professional development: results, reflections and implications, British Journal of Religious Education, 38:2, 189-199.

Van Manen, M. (1997). Researching lived experience: human science for an action sensitive pedagogy. (2. ed.) Ontario: Althouse press.

Van Manen, M. \& Li, S. (2002). The pathic principle of pedagogical language, Teaching and teacher education, $18,215^{-224}$. 